\title{
The effect of BMP4 on mouse embryonic stem cell proliferation and differentiation into primordial germ cells
}

\author{
Ghasemi Hamidabadi $\mathrm{H}^{1}$, Nazm Bojnordi $\mathrm{M}^{2}$, Azizi $\mathrm{H}^{3}$, Rezaie $\mathrm{N}^{4}$ \\ 1. Associated Professor of Anatomy Sciences, Department of Anatomy and Cell Biology, Immunogenetics Research Center, \\ Faculty of Medicine, Mazandaran University of Medical Sciences, Sari, Iran. ORCID ID: 0000-0002-2278-6503 \\ 2. Assistant Professor of Anatomy, Department of Anatomy and Cell Biology, Immunogenetics Research Center, Faculty of \\ Medicine, Mazandaran University of Medical Sciences, Sari, Iran (Corresponding Author), Tel: +98-1133542429, Email: \\ bojnordim@yahoo.com, ORCID ID: 0000-0003-1176-2417 \\ 3. Assistant Professor of Cell Biology, Department of Biotechnology, Amol University of Special Modern Technologies, \\ Amol, Iran.
}

4. Associated Professor of Anatomy Sciences, Department of Anatomy and Cell Biology, Immunogenetics Research Center, Faculty of Medicine, Mazandaran University of Medical Sciences, Sari, Iran.

\begin{abstract}
Background and Aim: Artificial gamete production from stem cells is a novel strategy for treatment of infertility. Among various stem cell sources, embryonic stem cells (ESC) can be considered as an appropriate source for in vitro formation of germ cells. In this study we evaluated the effect of BMP4 on proliferation and differentiation of mouse embryonic stem cells into primordial germ cells (PGCs).

Materials and Methods: Embryonic stem cells (ESC) were cultured in ES medium. At first, embryoid bodies (EBs) were formed by hanging drop method, and then were differentiated into primordial germ cells at different concentrations of BMP4 (10, 50 and $100 \mathrm{ng} / \mathrm{ml})$. The viability and proliferation rate of treated cells with BMP4 were evaluated by MTT assay. The EBs were cultured in induction medium. Expression of Oct4 'Stella and Mvh genes were evaluated by real time PCR.
\end{abstract}

Results: In the group treated with BMP4 for 7 days, maximum cell viability was detected at the concentration of $10 \mathrm{ng} / \mathrm{ml}$. But the groups treated with $100 \mathrm{ng} / \mathrm{ml}$ of BMP4 showed minimum cell viability. Maximum expression of Stella and $M v h$ genes were detected at the concentration of $10 \mathrm{ng} / \mathrm{ml}$ of BMP4 in the treated group.

Conclusion: The results showed that BMP4 can promote proliferation and differentiation of ES in vitro. Also different concentrations of BMP4 showed different effects on in vitro differentiation of ES into germ cells.

Keywords: Embryonic stem cells, Proliferation, Primordial germ cells, Viability, Embryoid Bodies

Received: Jan 7, $2019 \quad$ Accepted: June 30, 2019

How to cite the article: Ghasemi Hamidabadi H, Nazm Bojnordi M, Azizi H, Rezaei N. The effect of BMP4 on mouse embryonic stem cell proliferation and differentiation into primordial germ cells. SJKU 2019;24(3):110-120. 


\section{تاثير BMP4 بر تكثير و تمايز سلول هاى بنيادى جنينى به سلول هاى زاياى بدوى در شرايط آزمايشكاهى}

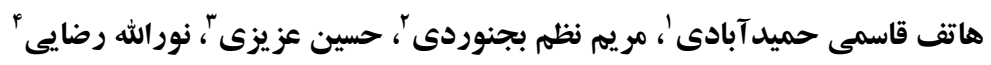

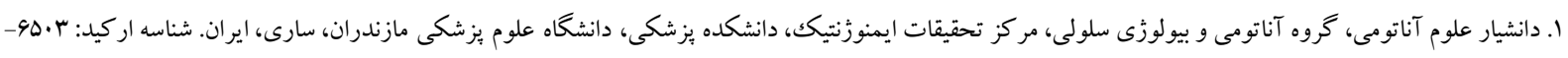

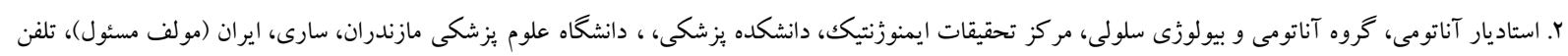

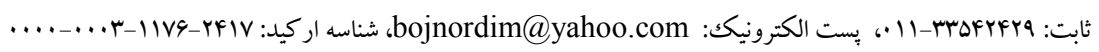

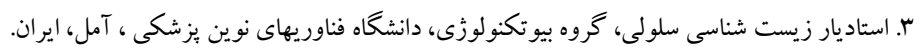

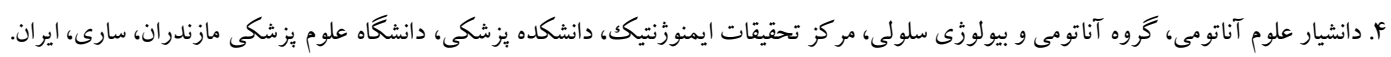

\section{جكيده}

زمينه و هدف: توليد آزمايشگاهى كامت از سلول هاى بنيادى به عنوان يكى از گزينه هاى جديد درمانى نابـارورى، مطرح مسى

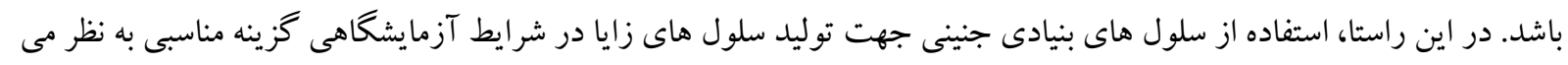

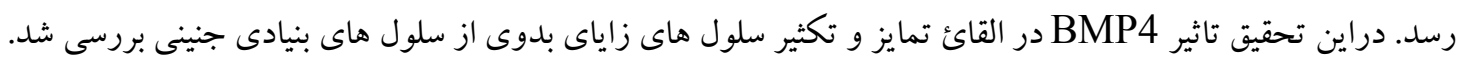

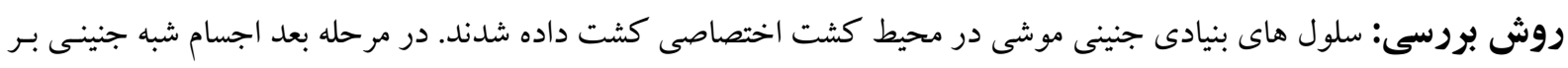

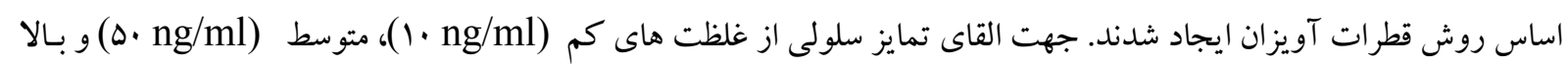

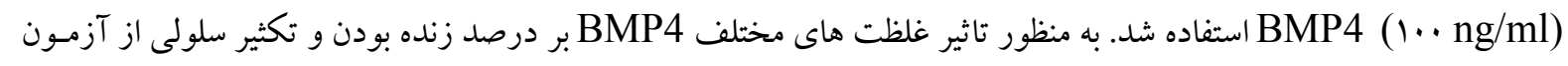

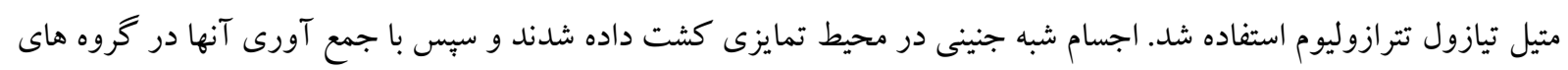

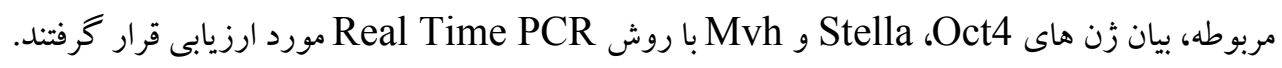

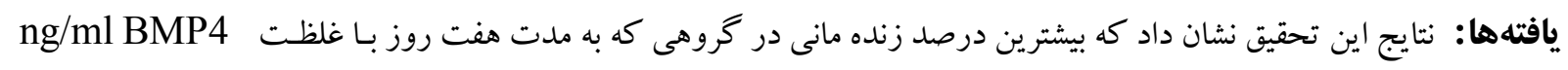

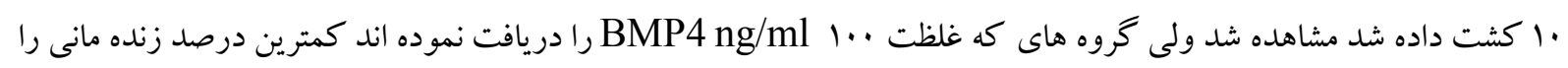
نشان دادند. همجنين بيشترين ميزان بيان ماركرهاى سلول هاى زاياى بدوى نظير Mvh و

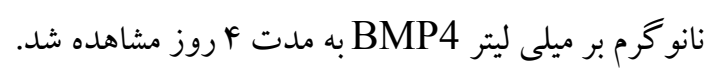

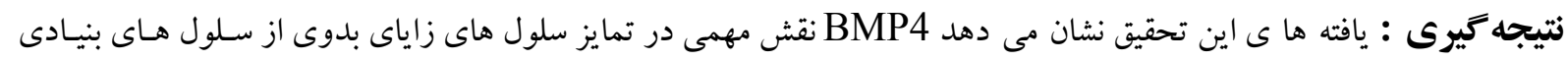

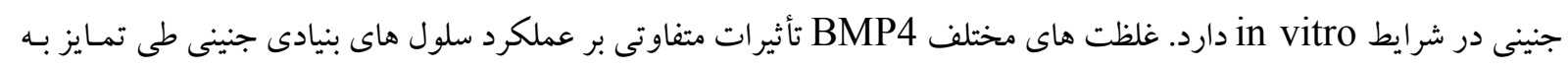

$$
\text { سمت رده هاى جنسى زايا در شرايط آزمايشكاهى دارند. }
$$

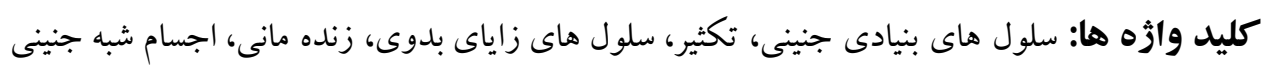

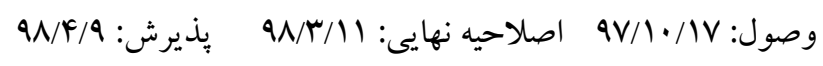


جنينى به سلول هاى زايا و تكثير آنها مى گردد. سلول هـاى بنيادى يا سـلول هـاى اجسام شبه جنينى در حضور اسـيد

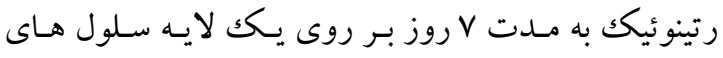

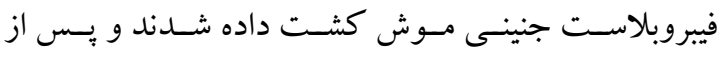
ارزيابى ماركر SSEA1 مشخص شد كه تمامى سلول هاى بيان كننده SSEA1 ، سلول هاى زاياى بدوى هستند (•). هر جند كه مطالعاتى در زمينه تمايز گامت جنسى از سلول

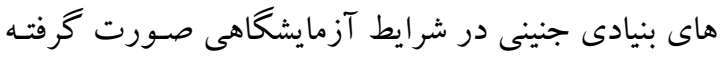

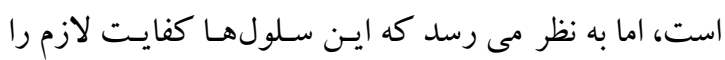
نخو اهند داشت بنابر اين به تكنيكك ها و سيستم هاى كشتى دهى

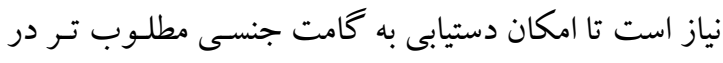
محيط كشت فراهم كردد. دراين تحقيق سعى شده كه تاثير

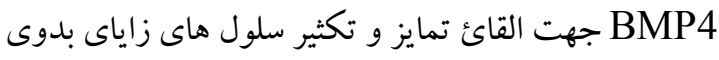
از سلول هاى بنيادى جنينى استفاده شود.

روش بررسى كشت سلولهاى بنيادى جنينى در يروهش فوق از رده سلول هـاى بنيـادى جنينى موشى جني

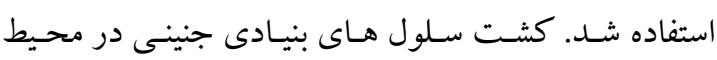
كشت DMEM حاوى سـديم ييروات وسرم Calf Serum) FCS كلو تامكس، اسيد آمينه غير ضـرورى، بتـا مر كإيتواتـانول، فاكتور مهار كننده لوسمى انجام شد. شكل گيرى اجسام شبه جنينى (Embryoid Bodies):

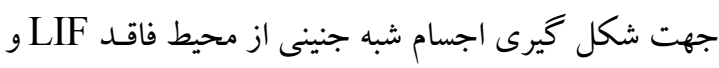
روش قطرات آويزان استفاده شد. بدين ترتيب سوسيانسيون

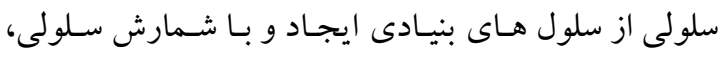

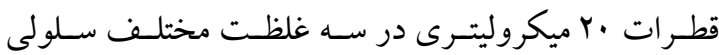

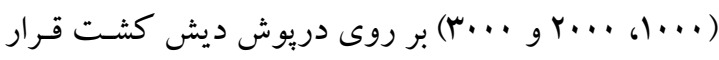

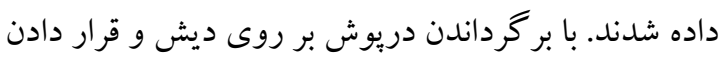

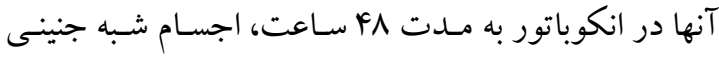
تشكيل شدند. سيس اجسام شبه جنينى توسط ميكروسكوب

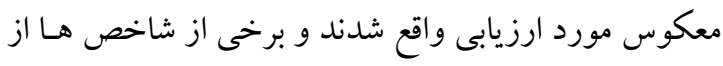

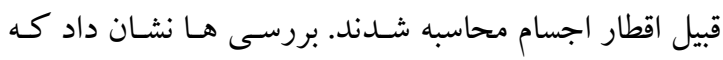

بيشرفت هاى نوين درمان نابارورى مبتنى بـر تكنيكك هـاى

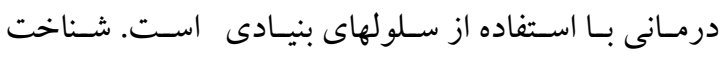
مكانيسم هاى زنتيكى و تكاملى در تكثير و تمايز سلول هاى بـاي

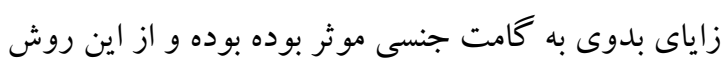
مى توان جهت درمان نابارورى بيمـاران استفاده كرد (1). توليد آزمايشگاهى كامت از سلول هاى بنيـادى در دو دهـــ تونه كذشته، به عنوان يكى از ززينه هاى درمانى در زمينه طـب إنب

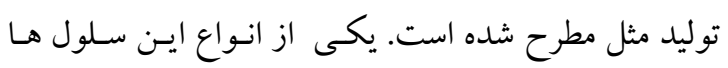

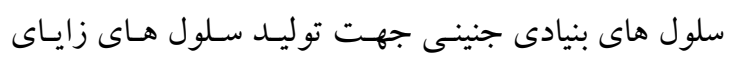

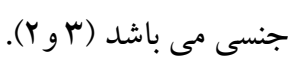
جهت متمايز شدن سلول زايا از سلول هـاى بنيـادى جنينى

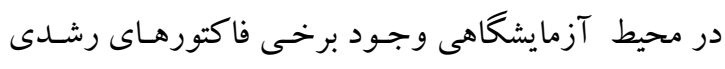

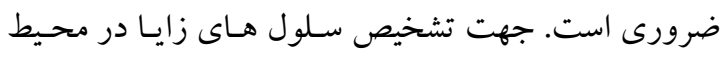

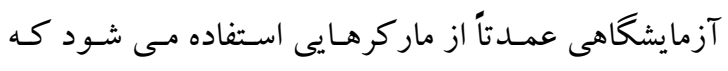

$$
\text { خاص سلول هاى زايا هستند (م ، F). }
$$

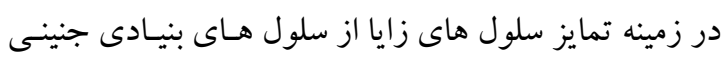

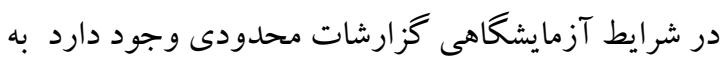
طور مثال درمطالعه اي سلول هاى بنيـادى جنينى بـه سـلول هاى شبه زاياى بدوى متمايز شدند وشناسايى و غنى سـازى مانى

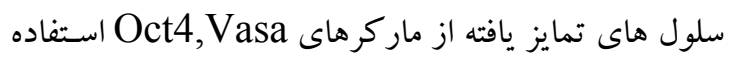

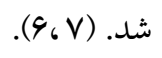
مطالعات بعدى درباره تمايز سلول هاى زايـا از سـلول هـاى

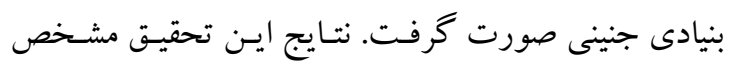
كرد كه پِ از هم كشتى سلول هاى زايـاى مشـتق شـده از

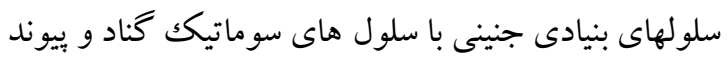

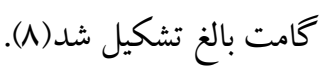

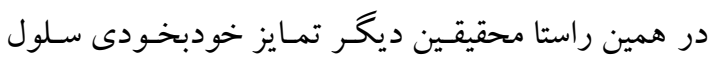

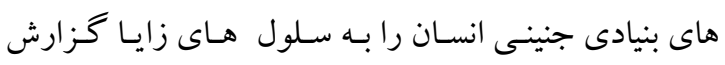
كردند (9). در تحقيق ديخرى به منظور تمـايز سـلول هـاى انسي

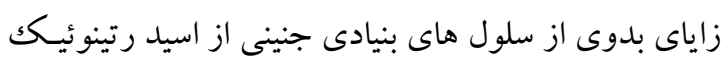

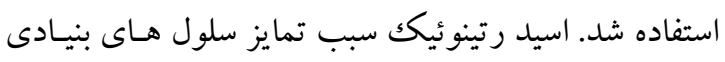




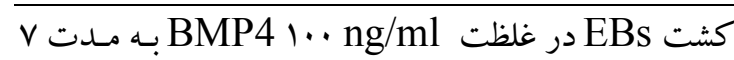

$$
\text { روز: گروه D100 }
$$

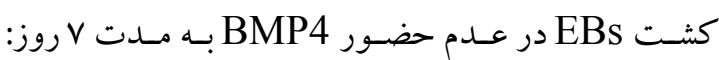

$$
\text { گروه D7B0 }
$$

ارزيابى درصد زنده بودن (Viability) و تكثير سلولى:

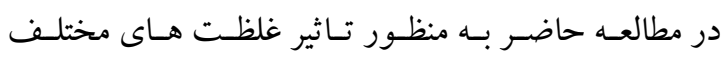
BMP4 بر درصد زنـده بـودن و تكثير سـلولى از آزمسون

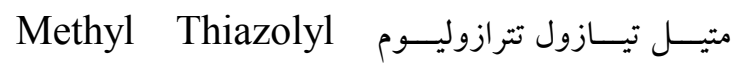
Tetrazolium (Sigma-Aldrich, MTT) شد. بدين ترتيب كه ابتدا اجسام شببه جنينى در هر گحروه جمع آورى شدند و با افزودن تريسين - EDTA و بيبيتاز،

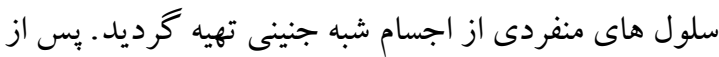

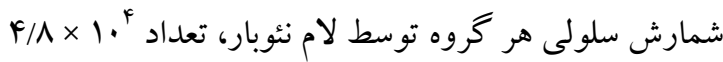

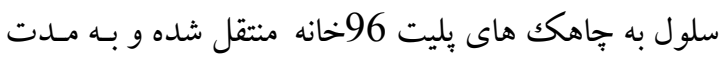

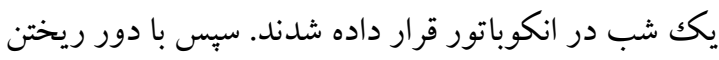
محيط كشت، •ه ميكروليتر از محلول MTT به هر يكك از

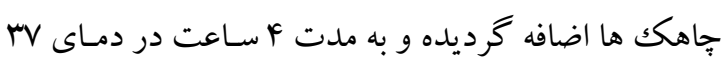

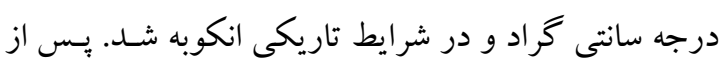

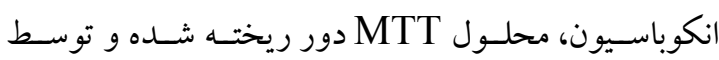

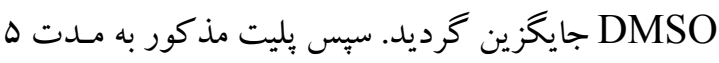

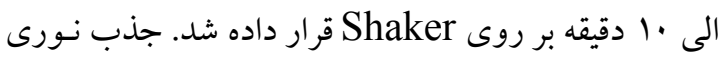

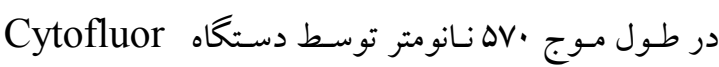
4000 plate reader (PerSeptive Biosystems, Framingham, Massachusetts, USA) كرفت. همجنين آزمايش ها سه بار تكرار شدند(rاו).

ارزيابى كمى ميزان بيان زن هـاى Stella OCt4

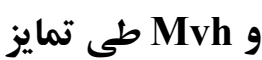
اجسام شبه جنينى در محيط تمايزى حاوى غلظت هاى كم،

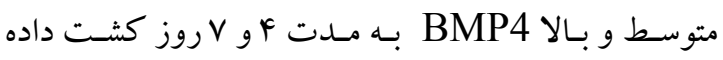
شدند. سبس با جمع آورى آنها در گروه هاى مربوطه، بيان

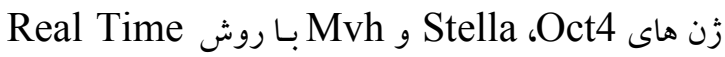
مو رد ارزيابى قرار گر فتند. ابتدا اجسام شبه جنينى در رو

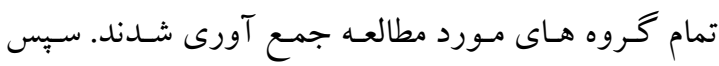

مناسب ترين شرايط براى ايجاد اجسام شبه جنينى با كيفيت بالا، غلظت . .... است (1). نحوه محاسبه اقطار و Ratio: نسبت حجم بـه سطح اجسام شبه جنينى Ratio در نظر

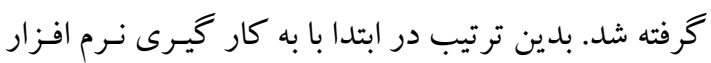

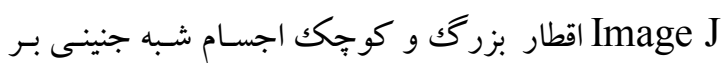
حسب ميلى متر محاسبه شدند(Y) (Y).

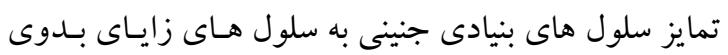
:BMP4 توسط فاكتور رشد (PGCs)

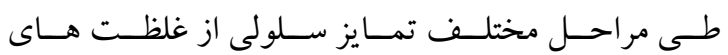

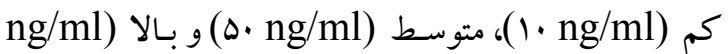
(BMP4) ( ) استفاده شد. كشت EBs در غلظت هاى مختلف BMP4: در اين تحقيق از غلظت هاى مختلف BMP4 استفاده شد. بدين ترتيب كه اجسام شبه جنينى در روز دوم (D2) جمع آدئ

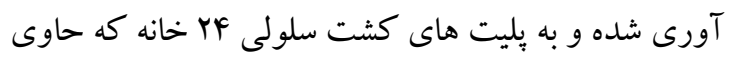

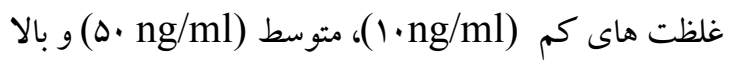

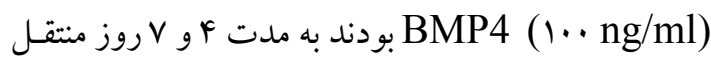

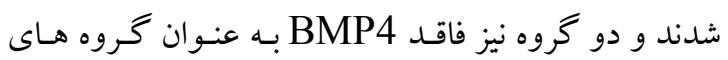

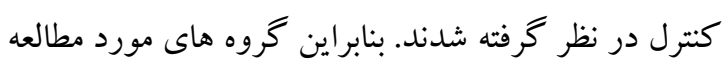
در اين قسمت از تحقيق شامل: كشت EBs در غلظت BMP4 1. ng/ml بـه مـدت روز: خروه D4B10 كشت EBs در غلظت روز: گروه S4B50

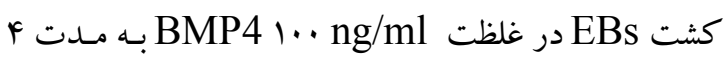
روز: گرووه D4B100

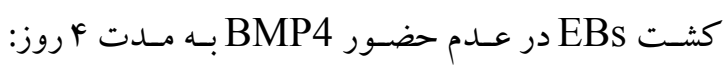
گروه D4B0

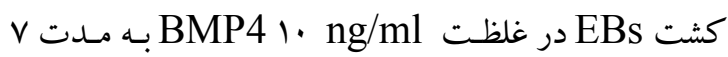
روز: گروه S7B10

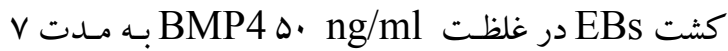
روز: كروه D7B50 
كل اسـتخراج و يـس از سـاخت cDNA Real-Time PCR

شكل كيرى اجسام شـبه جنينـى در غلظـت هـاى

مختلف سلولى

يافته هاى اين بخش نشان داد كـه اختلاف معنى دارى در

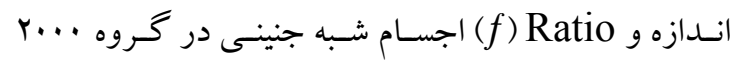

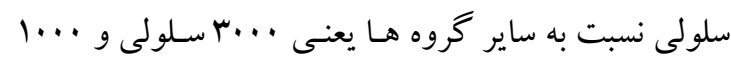

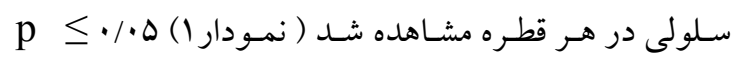
معنى دار در نظر گرفته شد. value

\section{روش آمارى}

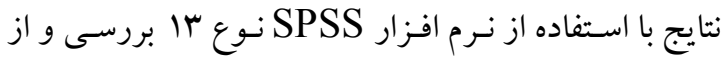

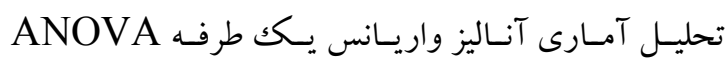

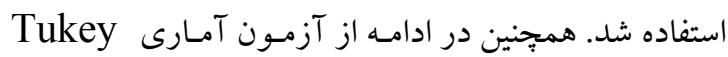
Test كرفته شد.

Size of EBs

○्-
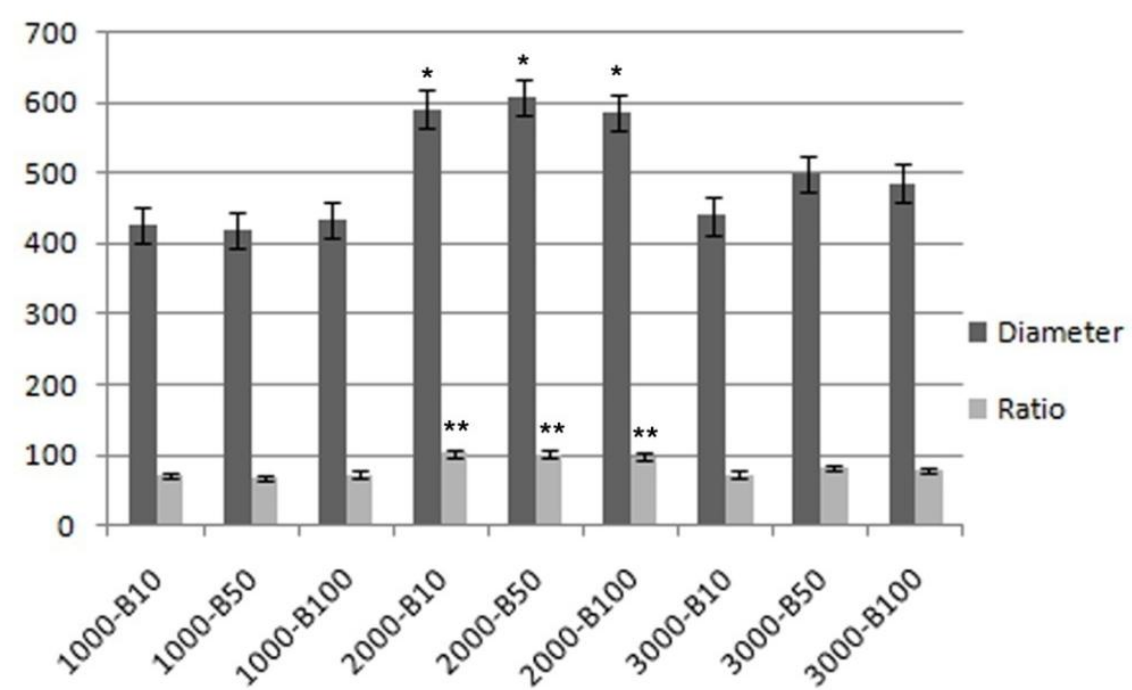

نمو دار ا: تاثير هم زمان غلظت هاى مختلف سلولى و BMP4 بر اندازه اجسام سبه جنينى (EBs).

غلظت . BMP4 ng/ml 1. را دريافت نموده اند (خروه هاى D4B100 و Dمت D7B100) كترين درصد زنده مـانى را دارا بودند. در ادامه مشخص شد كه تفـاوت معنى دارى

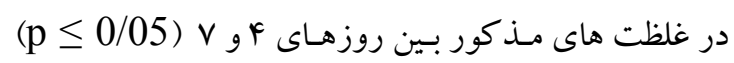
مشاهده شد (جدول ا و نمودار r).
ارزيسابى سـلول هـاى زايـاى بــدوى تمـايز يافته در حضـور غلظت هاى مختلف BMP4 ارزيابى ميزان زنده بودن (Viability) طى تمايز:

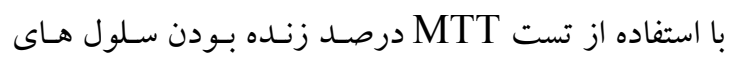
زاياى بدوى تمايز يافته در حضـور غلظـت هـاى ·له، ·لهو

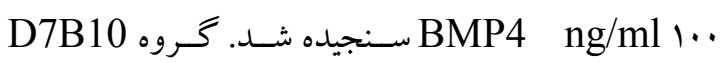
بيشترين درصد زنده مانى را دارا بودند اما گرووه هـاى كـه 
جدول ا: درصد زنده بودن سلول هاى تمايز يافته در غلظت هاى مختلف BMP4.

\begin{tabular}{|c|c|}
\hline $\begin{array}{l}\text { Bmp4 concentration } \\
(\mathrm{ng} / \mathrm{ml})\end{array}$ & $\begin{array}{c}\text { Viability percent } \\
(\text { Mean } \pm \text { SD) }\end{array}$ \\
\hline D4B10/D4B0 & $r v q \pm 9 r / 41$ \\
\hline D4B50/D4B0 & $10 \cdot \pm \psi \cdot / 1 \Delta$ \\
\hline D4B100/D4B0 & $|r| \pm F \Delta / 9 q$ \\
\hline D7B10/D7B0 & $r r \Delta \pm 1 \cdot V / \Lambda r$ \\
\hline D7B50/D7B0 & $r \mid r \pm r 1 / \cdots$ \\
\hline D7B100/D7B0 & $\| r \pm F r / v 1$ \\
\hline
\end{tabular}

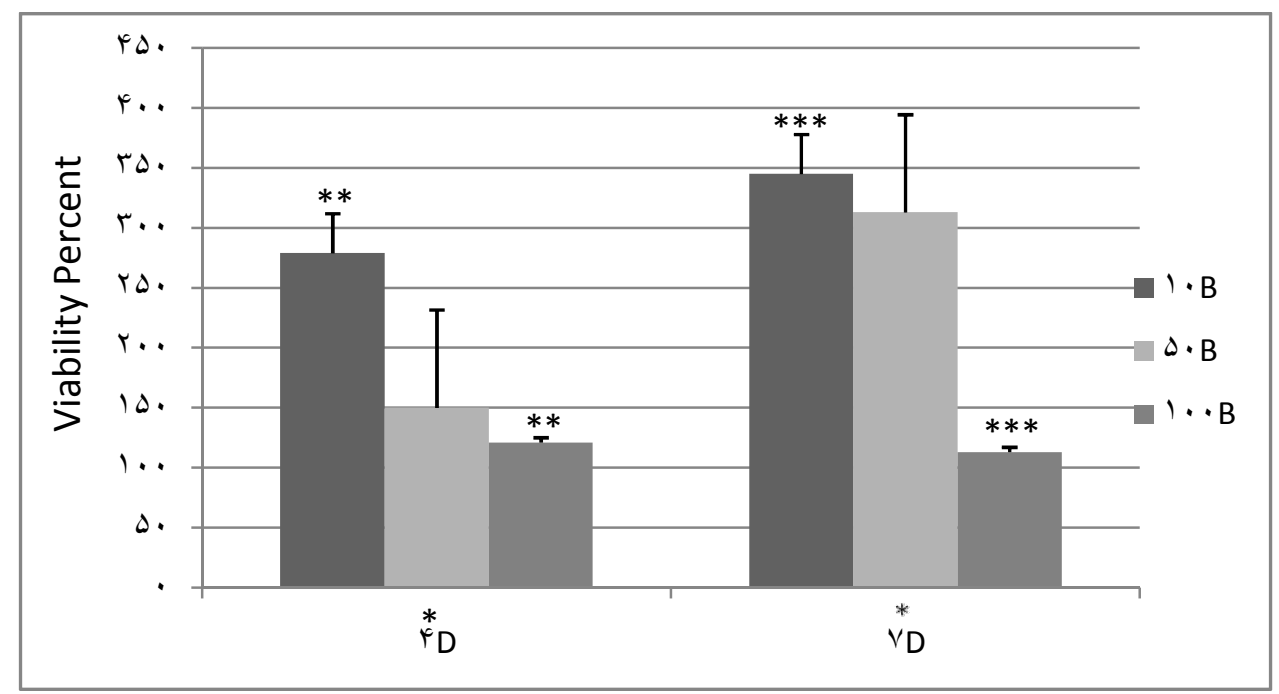

نمودار r: مقايسه درصد زنده بودن سلول هاى تمايز يافته در غلظت هاى مختلف BMP4.

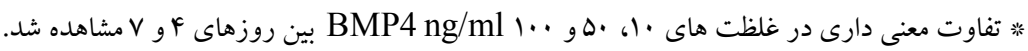

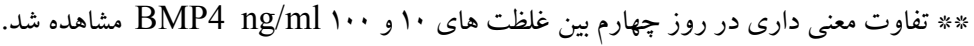

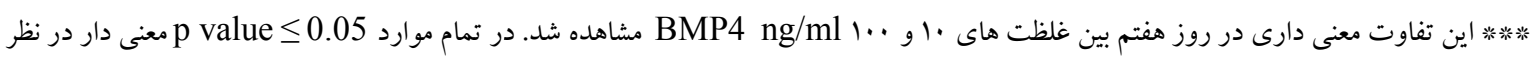
كرفته شد. 
مبر تكثير...

زن Stella در گروه هـاى كـه بـه مـدت ثا روز در معرض

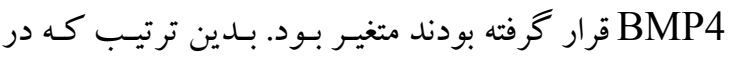

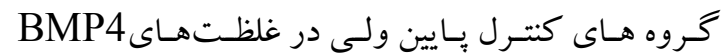

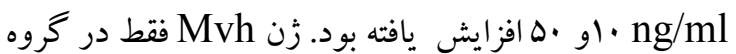

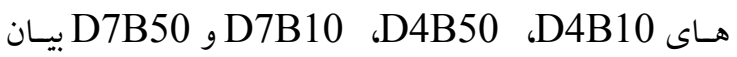
گرديد و حداكثر ميزان بيان آن در گروه D4B10 مشـاهده

$$
\text { شد (نمودار ب). }
$$

ارزيابى كمى ميزان بيـان زن هـاى Oct4، و و Stella يس از تمايز اجسام شبه جنينى

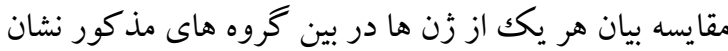

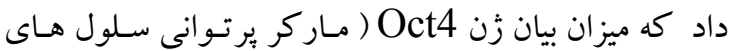

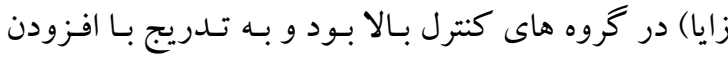

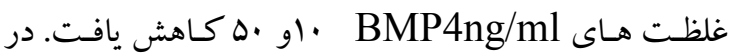
ادامه مشخص شد كه تفـاوت معنى دارى بين گرووه هـاى مختلف از نظرميزان بيان زن مـذكوروجود دارد. ميزان بيـان

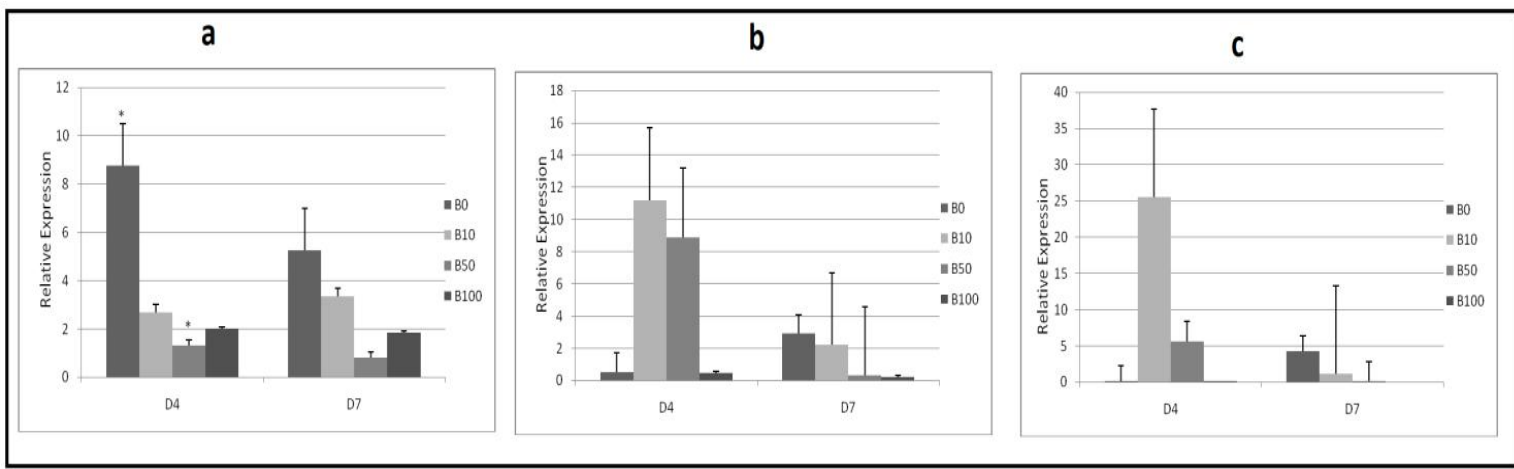

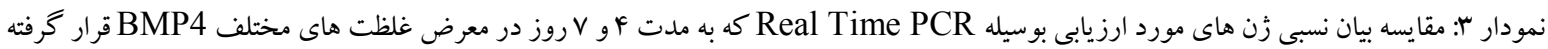

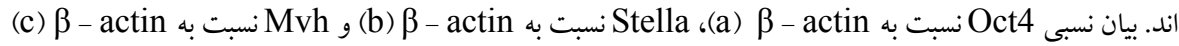

افزودن • ا نانو گرم بر ميلى ليتر BMP4 (غلظت كم) تأثير بهترى بر درصد زنده ماندن سلول هاى نسبت به ساير غلظت

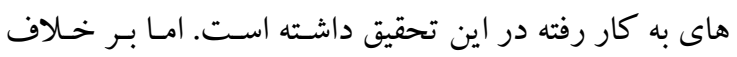

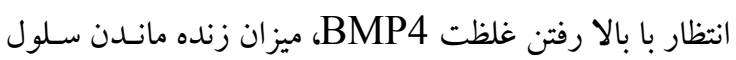
ها كاهش يافت. به نظر مى رسد كه غلظت هـاى متوسط و بالاى BMP4 اثر منفى بر زنده ماندن سلول ها داشته باشند.

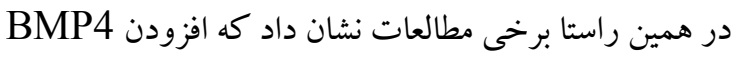
به محيط كشت وابسته به دوزبوده و بـر درصـد زنـده مانـدن

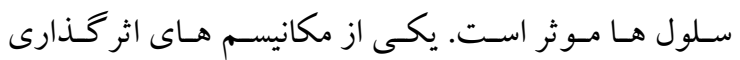

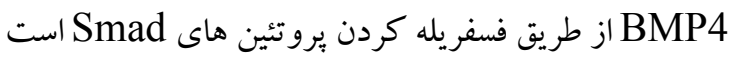
(11). محققان گزارش كردند كه BMP4 در كشت سلول كاملا وابسته به دوز است. به طورى كه با افزودن هانسانو گرم

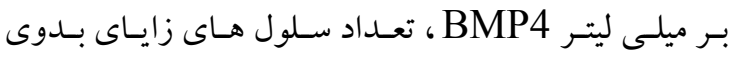

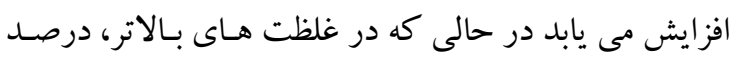

نتايج اين بررسى نشان داد كه BMP4 بـه عنـوان يـك القـا كننده مؤثر و توانا در تمـايز PGCs از سـلول هـاى بنيـادى جنينى موش مى باشد(1). سلول هاى بنيادى جنينى سـلول

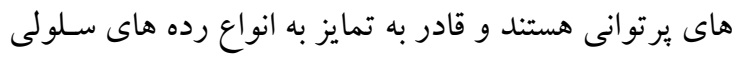

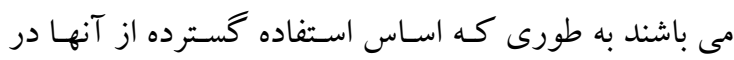

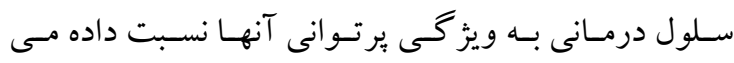

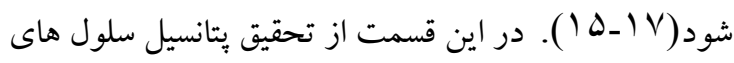
بنيادى جنينى موش جهت تمايز به بيس سازهاى سـلول زايـا

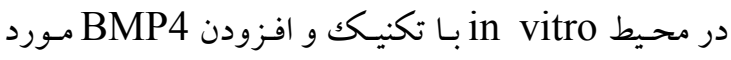

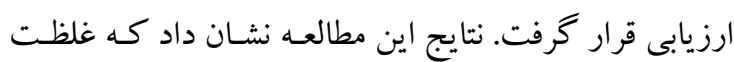

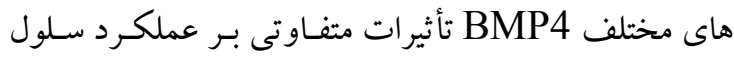

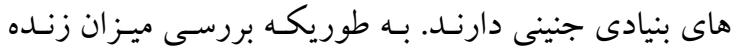

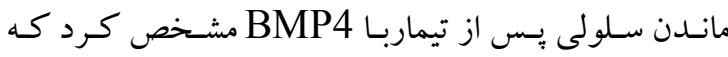


كه تنها در سلول هاى زاياى بدوى بروز بيدا مى كنــ. يافتهـ

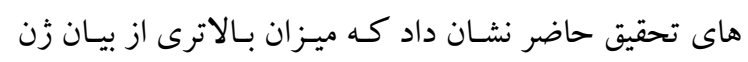

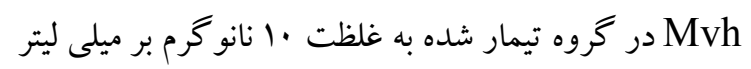

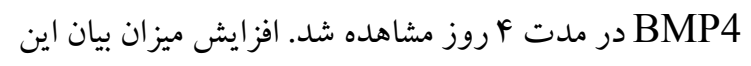

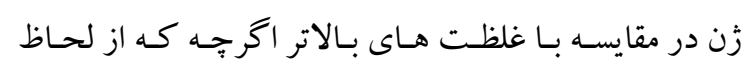

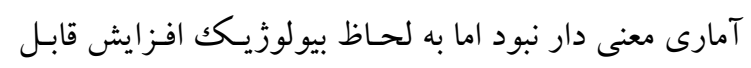
توجهى يافت. يافته هاى تحقيق حاضر تأييـدى بـر نتـايج سـاير محققين در

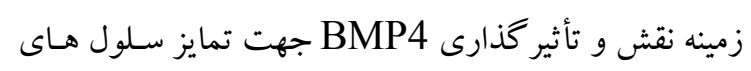

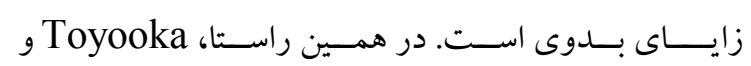

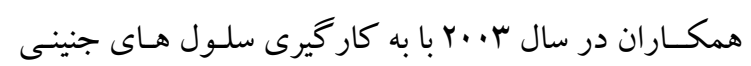
و درج كردن زن Mvh در سـاختار زنسومى ايـن سـلول هـا،

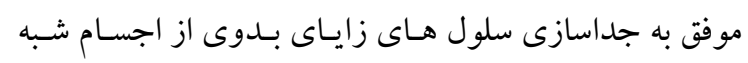

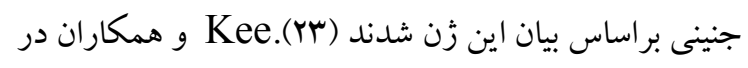

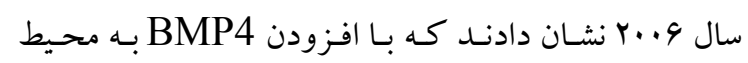

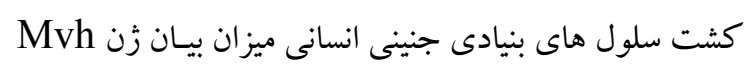

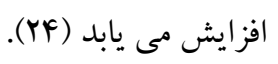

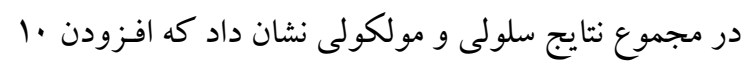

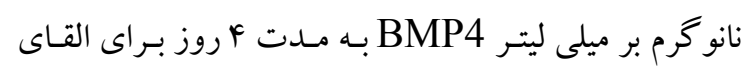

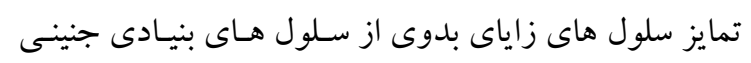

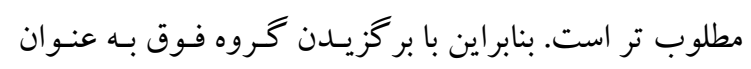

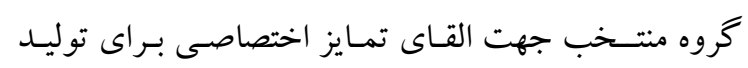
كامت جنسى در نظر گرفته خواهد شد.

نتيجه كيرى

BMP4 به عنوان عامل القا كننده مزودرمى نقش مهمسى در تمايز سلول هاى زاياى بدوى از سلول هاى بنيادى جنينى در

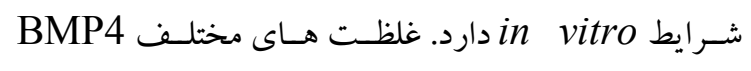

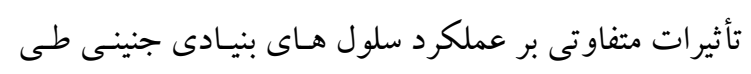

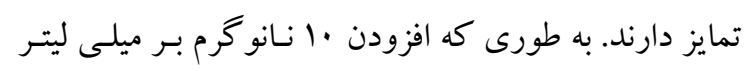

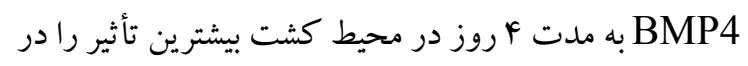

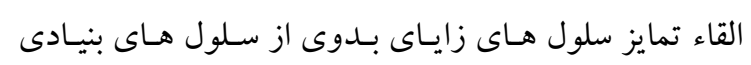

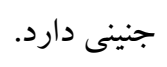

زنده ماندن سلول هاى مذكور كاهش ييدا مى كند (19). اما

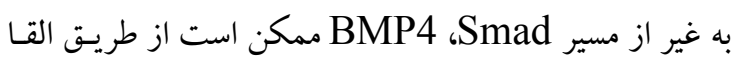
نمودن برخى زن هاى وابسته بـه بـروتئين كينـاز، در فر آينـد

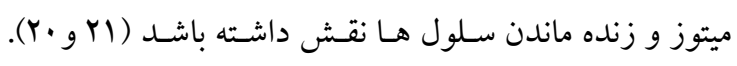

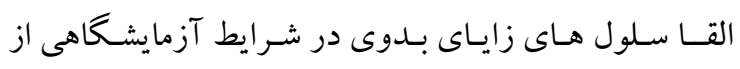

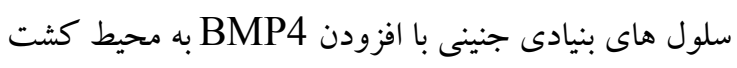

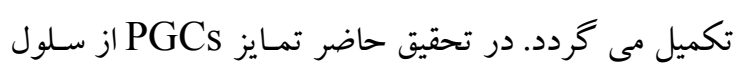
هاى بنيادى جنينى در حضور غلظت هاى مختلف مايف

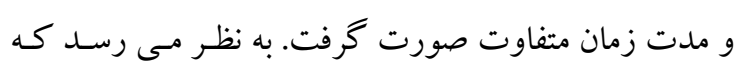

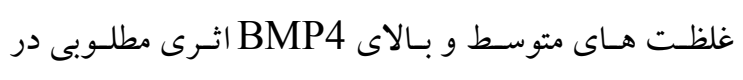
فر آيند تمايز PGCs از سلول هاى بنيادى جنينى ندارند.

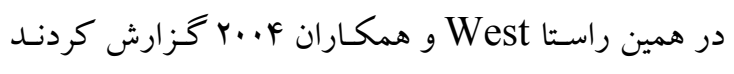

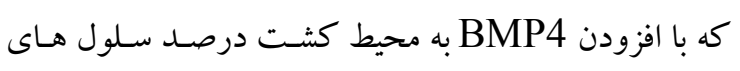
بيان كننده Vasa افزايش مى يابد و ذكر كردند كـه اثرات BMP4 كاملا وابسته به دوز است به طورى كه غلظت هاى كم BMP4 مؤثرتر است (YY) كافو وابته به دوز است

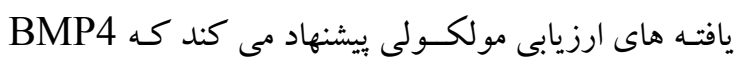

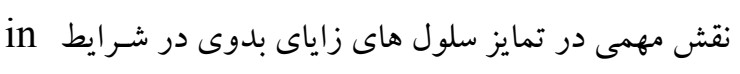
vitro تكامل سلول هاى زايـاى بـدوى سـنجيده شـــ ميزان بيـان

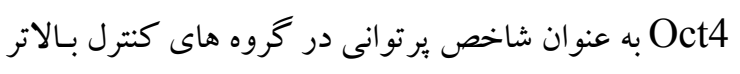

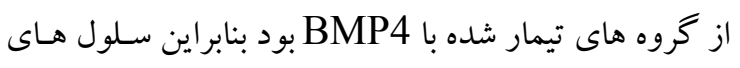
بنيادى جنينى Oct4 را تنها در حالت غير تمايزى بيان نموده اند و همزمان با شروع روند تمايز اين بيان كاهش يافته است

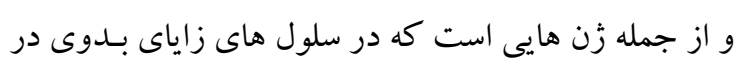

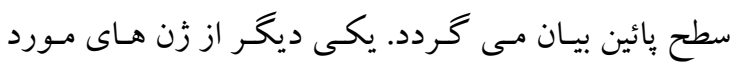

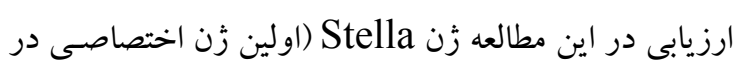
روند تكامل سلول هاى زايا كه در مرحله تمايز سـلول هـاى درّل

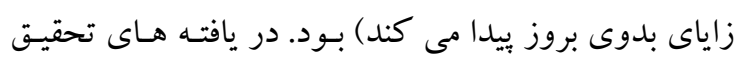

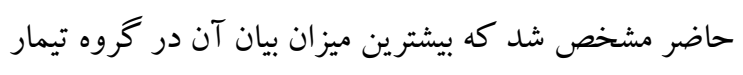

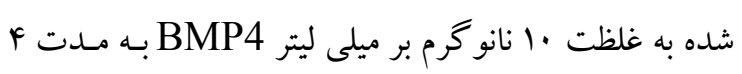

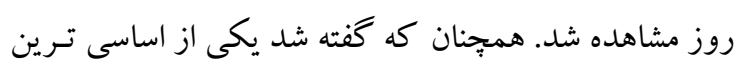

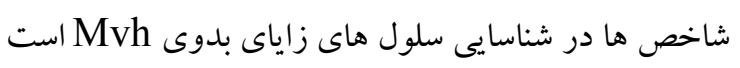




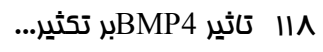

\begin{tabular}{|c|c|}
\hline كه نويسند گان بدينوسيله از كارشناسـان محترم آزمايشـگاه & \\
\hline گروه علوم تشريحى دانشگاه علوم يزشكى مازندران تقدير و & صـل بــروزه مصسوب معاونست تحقيقـات و \\
\hline 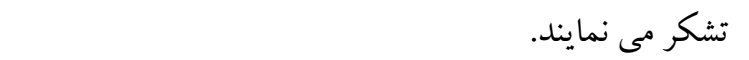 & ملوم يزشكى مازندران به كد 1718 اسـت \\
\hline
\end{tabular}

\section{References.}

1. Johnson AD, Richardson E, Bachvarova RF, Crother BI. Evolution of the germ line-soma relationship in vertebrate embryos. Reproduction 2011;141:291-300.

2. Kashir J, Jones C, Child T, Williams SA, Coward K. Viability assessment for artificial gametes: the need for biomarkers of functional competency. Biol Reprod 2012;87:114.

3. Irie N, Weinberger L, Tang WW, Kobayashi T, Viukov S, Manor YS, et al. SOX17 is a critical specifier of human primordial germ cell fate. Cell 2015;160:253-68.

4. Sugawa F, Arauzo-Bravo MJ, Yoon J, Kim KP, Aramaki S, Wu G, et al. Human primordial germ cell commitment in vitro associates with a unique PRDM14 expression profile. EMBO J 2015;34:1009-24.

5. Dominguez AA, Chiang HR, Sukhwani M, Orwig KE, Reijo Pera RA. Human germ cell formation in xenotransplants of induced pluripotent stem cells carrying $\mathrm{X}$ chromosome aneuploidies. Sci Rep 2014;4:6432.

6. Aramaki S, Hayashi K, Kurimoto K, Ohta H, Yabuta Y, Iwanari H, et al. A mesodermal factor, $\mathrm{T}$, specifies mouse germ cell fate by directly activating germline determinants. Dev Cell 2013;27:516- 29.

7.Hackett JA, Zylicz JJ, Surani MA. Parallel mechanisms of epigenetic reprogramming in the germline. Trends Genet 2012;28:164-74.

8. Koubova J, Menke DB, Zhou Q, Capel B, Griswold MD and Page DC: Retinoic acid regulates sex-specific timing of meiotic initiation in mice. Proc Natl Acad Sci USA 2006: 103: 2474-9.

9. Toyooka Y, Tsunekawa N, Akasu R and Noce T: Embryonic stem cells can form germ cells in vitro. Proc Natl Acad Sci U S A 2003:100:11457-62.

10. Ghasemi Hamidabadi H, Pasbakhsh P, Amidi F, Soleimani M, Forouzandeh M, Sobhani A. Functional Concentrations of BMP4 on Differentiation of Mouse Embryonic Stem Cells to Primordial Germ Cells. Int J Fertil Steril 2011;5:104-9.

11. Eskandari N, Hassani Moghaddam M, Atlasi MA, Amini Mahabadi J, Taherian A, Nikzad $\mathrm{H}$. The combination of retinoic acid and estrogen can increase germ cells genes expression in mouse embryonic stem cells derived primordial germ cells. Biologicals 2018;56:39-44.

12. Makoolati Z, Movahedin M, Forouzandeh-Moghadam M. Proliferation in culture of primordial germ cells derived from embryonic stem cell: induction by retinoic acid. Biosci Rep 2016; 36: e00428.

13. Bojnordi MN, Movahedin M, Tiraihi T, Javan M. A simple co-culture system for generation of embryonic stemlike cells from testis. Iran Red Crescent Med J 2012;14:811-5.

14. Bojnordi MN, Movahedin M, Tiraihi T, Javan M. Alteration in genes expression patterns during in vitro differentiation of mouse spermatogonial cells into neuroepithelial-like cells. Cytotechnology 2013;65:97-104.

15. Shah SM, Singla SK, Palta P, Manik RS, Chauhan MS. Retinoic acid induces differentiation of buffalo (Bubalus bubalis) embryonic stem cells into germ cells. Gene 2017;631:54-67. 
16. Haratizadeh S, Bojnordi MN, Niapour A, Bakhtiari M, Hamidabadi HG, Sari I. Improvement of neuroglial differentiation from human dental pulp stem cells using CSF. J Mazandaran Uni Med Sci 2016; 26:1-14. [In Persian]

17. Moayeri A, Bojnordi MN, Haratizadeh S, Esmaeilnejad-Moghadam A, Alizadeh R, Hamidabadi HG. Transdifferentiation of human dental pulp stem cells into oligoprogenitor cells. Basic and clinical neuroscience 2017;8:387.

18. Jung D, Xiong J, Ye M, Qin X, Li L, Cheng S, et al. In vitro differentiation of human embryonic stem cells into ovarian follicle-like cells. Nat Commun 2017;8:15680.

19. Gholamitabar Tabari M, Jorsaraei SGA, Ghasemzadeh-Hasankolaei M, Ahmadi AA, Mahdinezhad Gorji N. Evaluation of specific germ cell genes expression in mouse embryonic stem cell-derived germ cell like cells treated with bone morphogenetic protein 4 in vitro. Int Reprod Biomed (Yazd) 2018;16:507-18.

20. Gholamitabar Tabari M, Jorsaraei SGA, Ghasemzadeh-Hasankolaei M, Ahmadi AA, Ghasemi M. Comparison of germ cell gene expressions in spontaneous monolayer versus embryoid body differentiation of mouse embryonic stem cells toward germ cells. Int J Fertil Steril 2019;13:139-47.

21. Devika AS, Wruck W, Adjaye J, Sudheer S. The quest for pluripotency: a comparative analysis across mammalian species. Reproduction 2019;1: pii: REP-18-0083.R4.

22. West JA, Daley GQ. In vitro gametogenesis from embryonic stem cells. Curr Opin Cell Biol 2004:16: 688-92.

23. Toyooka Y, Tsunekawa N, Akasu R, Noce T. Embryonic stem cells can form germ cells in vitro. Proc Natl Acad Sci USA 2003:100:11457-62.

24. Kee K, Gonsalves JM, Clark AT, Pera RAR. Bone morphogenetic proteins induce germ cell differentiation from human embryonic stem cells. Stem Cells Dev 2006;15:831-7. 